\title{
POLITYKA RACHUNKOWOŚCI \\ A KSZTAŁTOWANIE WYNIKU FINANSOWEGO PRZEDSIĘBIORSTWA NA PRZYKLADZIE ZAPASÓW
}

\section{Wstęp}

Celem niniejszego artykułu jest zwrócenie uwagi na możliwość kształtowania wyniku finansowego w rezultacie przyjęcia i realizacji określonej przez przedsiębiorstwo polityki rachunkowości. Szczególna uwaga zostanie zwrócona na wybrane różnice pomiędzy polityką rachunkowości prowadzoną $\mathrm{w}$ oparciu o Ustawę o rachunkowości a politykę rachunkowości $\mathrm{z}$ uwzględnieniem Międzynarodowych Standardów Rachunkowości w odniesieniu do wyceny zapasów. W opracowaniu podniesiona zostanie także kwestia kierunku rozwoju rachunkowości oraz narzędzi służących ocenie sprawozdań finansowych przedsiębiorstw w perspektywie roku 2020.

Wyniki działalności przedsiębiorstwa, sytuacja finansowa i zmiany położenia finansowego przedstawiane są $\mathrm{w}$ okresowych sprawozdaniach finansowych, a korzysta $\mathrm{z}$ nich szerokie grono odbiorców, m.in. inwestorzy, właściciele i zarząd przedsiębiorstwa, kredytodawcy, pracownicy, kontrahenci, czy władze budżetowe.

Sprawozdanie finansowe zawiera zagregowane, przetworzone dane o zdarzeniach i transakcjach, które miały miejsce lub które dotyczą danego okresu sprawozdawczego. Podstawą tworzenia sprawozdania finansowego są dokonywane przez przedsiębiorstwo zapisy księgowe zdarzeń dotyczących działalności przedsiębiorstwa. Proces księgowania tych zdarzeń uregulowany jest wieloma przepisami prawa, które mają na celu zapewnienie rzetelnego przedstawiania transakcji, zgodnie z ich treścią ekonomiczną.

\section{Podstawy prawne sporządzania sprawozdań finansowych}

Podstawowe normy polskiej rachunkowości to:

- Ustawa o rachunkowości wraz z aktami wykonawczymi.

\footnotetext{
Doktorantka, Katedra Analizy i Strategii Przedsiębiorstwa, Wydział Ekonomiczno-Socjologiczny, Uniwersytet Łódzki.
} 
- Uchwały Komitetu Standardów Rachunkowości w sprawie przyjęcia Krajowych Standardów Rachunkowości.

- Rozporządzenie Komisji Europejskiej przyjmujące określone Międzynarodowe Standardy Rachunkowości, zgodnie z rozporządzeniem Parlamentu Europejskiego i Rady (WE) nr 1606/2002 z dnia 19 lipca 2002r.

- Inne przepisy odnoszące się do rachunkowości.

Większość przedsiębiorstw działających w polskiej gospodarce sporządza statutowe sprawozdanie finansowe stosując zasady określone w ustawie o rachunkowości (dalej: UoR). Przywołana ustawa wskazuje także podmioty, które obligatoryjne lub fakultatywnie stosują do sporządzania sprawozdań finansowych przepisy zawarte w Międzynarodowych Standardach Rachunkowości, przyjęte przez Komisję Europejską.

W ostatnich latach na szczeblu Unii Europejskiej wyraźnie widoczne były działania $\mathrm{w}$ kierunku harmonizacji przepisów rachunkowych i sporządzanych $\mathrm{w}$ oparciu o nie sprawozdań finansowych spółek notowanych na giełdach papierów wartościowych, głównie $\mathrm{w}$ celu zagwarantowania porównywalności informacji i ochrony interesów inwestorów. Stosowanie międzynarodowych zasad rachunkowości ma na celu wzmocnienie zaufania na rynkach finansowych, ułatwiając jednocześnie międzynarodowy obrót papierami wartościowymi.

Polskie przepisy również zmierzają $\mathrm{w}$ kierunku harmonizacji przepisów o rachunkowości ze standardami międzynarodowymi. Zgodnie z art. 45 ustawy o rachunkowości ${ }^{1}$ do podmiotów, które mogą sporządzać sprawozdania finansowe zgodnie z MSR zalicza się emitentów papierów wartościowych dopuszczonych, zamierzających ubiegać się lub ubiegających się o ich dopuszczenie do obrotu na jednym z rynków regulowanych krajów należących do Europejskiego Obszaru Gospodarczego. Dobrowolność stosowania MSR odnosi się również do jednostek wchodzących w skład grupy kapitałowej, której jednostka dominująca sporządza skonsolidowane sprawozdanie finansowe zgodnie $\mathrm{z}$ MSR oraz do oddziałów przedsiębiorcy zagranicznego, jeżeli przedsiębiorca ten sporządza sprawozdanie finansowe zgodnie $\mathrm{z}$ Międzynarodowymi Standardami Rachunkowości. W przypadku wyżej wymienionych jednostek decyzję

\footnotetext{
${ }^{1}$ Ustawa z dnia 29 września 1994 r. o rachunkowości, tj. Dz.U. 2009, nr 152, poz. 1223 z późn. zm., art.3 ust. 1 pkt. 11.
} 
dotyczącą sporządzenia sprawozdania finansowego, zgodnie z MSR, podejmuje organ zatwierdzający sprawozdanie finansowe ${ }^{2}$.

Ustawa $^{3}$ wskazuje na ogólne zasady rachunkowości, jednak wiele może zmienić ustalona i przyjęta przez podmiot prowadzący działalność gospodarczą polityka rachunkowości. Ustawa o rachunkowości, zwana prawem bilansowym, z jednej strony stanowi o budowie, organizacji i funkcjonowaniu systemu rachunkowości, z drugiej zaś pozostawia podmiotowi swobodę działania i stwarza możliwość wyboru rozwiązań wariantowych. W wybranych obszarach, w których prawo bilansowe pozwala na taką dowolność, podmioty mogą przyjmować regulacje wskazane $\mathrm{w}$ ustawach podatkowych w prowadzonej polityce rachunkowości. Jest to ułatwienie, mające na celu niestosowanie dwóch odmiennych podejść - dla celów rachunkowości i dla celów podatkowych.

Polityka rachunkowości stanowi najważniejszy dokument opisujący rachunkowość jednostki. Ustawa o rachunkowości definiuje zasady (politykę) rachunkowości jako wybrane i stosowane przez jednostkę rozwiązania dopuszczone ustawą, w tym także określone w MSR, zapewniające wymaganą jakość sprawozdań finansowych. W polityce rachunkowości nie wprowadza się zapisów dotyczących rozwiązań wynikających wprost z przepisów prawa bilansowego, co do których nie pozostawia ona wyboru oraz które są obligatoryjnie stosowane ${ }^{4}$. Takimi właśnie regulacjami są obecnie Międzynarodowe Standardy Rachunkowości (MSR)/Międzynarodowe Standardy Sprawozdawczości Finansowej (MSSF). Powstały one wskutek trwających od kilkudziesięciu lat procesów harmonizacji i standaryzacji rachunkowości, znajdujących odzwierciedlenie w regulacjach prawnych, szeroko opisywanych w literaturze przedmiotu 5 .

2 M. Pęksyk, Zestawienie podobieństw i różnic pomiędzy MSSF/MSR aUstawa o Rachunkowości, materiał szkoleniowy Eurofinance Training 2012.

${ }^{3}$ Ustawa z dnia 29 września 1994 r. o rachunkowości, tj., Dz.U. 2009, nr 152, poz. 1223 z późn. zm.

4 Jak ustalić własna polityke rachunkowości?, „Zeszyty Metodyczne Rachunkowości”, nr 7(295), Dodatek nr 7, Wydawnictwo Podatkowe GOFIN, 2011, s. 2.

5 E. Walińska, A. Wencel, J. Gad, A. Jurewicz, Sprawozdanie finansowe wedlug MSSF, Wolters Kluwer, Warszawa, 2011, s. 19. 


\section{Różnice w wycenie aktywów przedsiębiorstwa z zastosowaniem ustawy o rachunkowości i MSR na przykładzie wyceny zapasów}

Pomimo, że ustawa o rachunkowości jest stopniowo harmonizowana z Międzynarodowymi Standardami Rachunkowości, można doszukać się wielu rozbieżności pomiędzy tymi regulacjami. Dotyczą one w szczególności wyceny aktywów i zobowiązań oraz ujmowania przychodów i kosztów, które niewątpliwie kształtują wynik finansowy przedsiębiorstwa. Przykłady różnic w odniesieniu do ujmowania pozycji ,zapasy” prezentuje tabela 1 .

Tabela 1. Różnice pomiędzy ustawą o rachunkowości a MSR/MSSF w zakresie wyceny zapasów

\begin{tabular}{|l|l|l|}
\hline \multicolumn{1}{|c|}{ UoR $^{\mathbf{6}}$} & \multicolumn{1}{|c|}{ MSR/MSSF } & \multicolumn{1}{c|}{ Komentarz } \\
\hline Art. 3 ust.1, pkt 19 & MSR 2 & Różnice dotyczą: \\
Zapasy to rzeczowe & Zapasy to aktywa: & wyceny rozchodu \\
aktywa obrotowe, & a) przeznaczone do & $\begin{array}{l}\text { zapasów - MSR 2 nie } \\
\text { przez które rozumie się }\end{array}$ \\
materiały nabyte w & sprzedaży w toku & pozwala na wycenę \\
celu zużycia na własne & gospodarczej; & rozchodu metodą \\
potrzeby, wytworzone & b) będące w trakcie & LIFO oraz metodą \\
lub przetworzone przez & produkcji & szczegółowej, \\
jednostkę produkty & przeznaczonej na & wg MSR 2 \\
gotowe (wyroby i & taką sprzedaż; lub & kapitalizacji wartości \\
usługi) zdatne do & c) mające postać & zapasów nie mogą \\
sprzedaży lub w toku & materiałów lub & podlegać różnice \\
produkcji, półprodukty & dostaw surowców & kursowe, co jest \\
oraz towary nabyte w & zużywanych w & dozwolone zgodnie z \\
celu odprzedaży w & procesie & UoR, jeżeli \\
stanie & produkcyjnym lub w & uzasadnione jest to \\
nieprzetworzonym; & trakcie świadczenia & długotrwałym \\
& usług. & przygotowaniem \\
& & produktu do \\
& & sprzedaży, \\
\hline
\end{tabular}

Źródło: na podstawie UoR i Rozporządzenia Komisji (WE) w sprawie MSR.

\footnotetext{
${ }^{6}$ Ustawa z dnia 29 września 1994 r. o rachunkowości, tj. Dz.U. 2009, nr 152, poz. 1223 z późn. zm., art.3 ust. 1 pkt. 11.

7 Rozporządzenie Komisji (WE) Nr 1126/2008 z dnia 3 listopada 2008 r. przyjmujące określone międzynarodowe standardy rachunkowości zgodnie z rozporządzeniem (WE) nr 1606/2002 Parlamentu Europejskiego i Rady, Dziennik Urzędowy Unii Europejskiej z dnia 29.11.2008, PL.
} 
Tabela 1. Różnice pomiędzy ustawą o rachunkowości...

\begin{tabular}{|l|l|l|}
\hline \multicolumn{1}{|c|}{ UoR } & \multicolumn{1}{|c|}{ MSR/MSSF } & \multicolumn{1}{c|}{ Komentarz } \\
\hline Art. 28. zapasy & Zapasy ujmuje się w & koszty finansowania \\
wycenia się według & kwocie niższej & zewnętrznego (zwykle \\
cen nabycia lub & spośród dwóch & odsetki), służące \\
kosztów wytworzenia & następujących: ich & wytwarzaniu zapasów \\
nie wyższych od cen & kosztu zakupu (ceny & w długim procesie, \\
ich sprzedaży netto & nabycia) oraz ceny & wg MSR 23 mogą być \\
UoR dopuszcza & sprzedaży netto. & zaliczane także w \\
wycenę rozchodu & MSR 2 nie zezwala & czéści tych kosztów, \\
zapasów z & na stosowanie & które nie są \\
zastosowaniem metod: & metody LIFO. & ponoszone na \\
FIFO (pierwsze & & wytworzenie \\
przyszło - pierwsze & & konkretnie tych \\
wyszło), LIFO & & aktywów, w \\
(ostatnie przyszło - & & niektórych \\
pierwsze wyszło), cen & & okolicznościach \\
przeciętnych oraz & & wycena bilansowa \\
szczegółowej & & według zasady niższej \\
identyfikacji cen. & & z wartości ceny \\
& & realizacji netto i ceny \\
& & nabycia \\
& & (wytworzenia) nie \\
& & obowiązuje (gdy dany \\
& & zapas może być ujęty \\
& & w innym składniku \\
& & aktywów, którego \\
& & cena sprzedaży \\
& & pokrywa koszt (cenę \\
& & nabycia lub koszt \\
& & wytworzenia) danego \\
& & składnika zapasów. \\
\hline
\end{tabular}

Źródło: na podstawie UoR i Rozporządzenia Komisji (WE) w sprawie MSR.

Wycena zapasów, materiałów, towarów oraz produktów składników majątku obrotowego przedsiębiorstwa zgodnie $\mathrm{z}$ przepisami rachunkowymi wymaga stosowania jednej $\mathrm{z}$ metod w danym okresie sprawozdawczym. W konsekwencji wybrana metoda służyć będzie także wycenie zapasu końcowego na potrzeby sporządzenia bilansu. Metody wyceny zapasów są ważne, ze względu na fakt, iż ceny kupowanych materiałów oraz ogólne koszty produkcji zmieniają się w czasie. W praktyce gospodarczej, znajdujące się w magazynie zapasy są przyjmowane po różnych cenach. Wydając z magazynu zapas, przedsiębiorstwo musi zdecydować po jakiej cenie 
zaksięgować jego wydanie. Jeżeli nie jest prowadzona ewidencja szczegółowa zapasów, przedsiębiorstwo nie jest w stanie dokładnie wskazać która ich część była przyjęta po której cenie, a jedynie ile zostało przyjęte po każdej $\mathrm{z}$ cen. Przedsiębiorstwo, podejmując decyzje $\mathrm{w}$ zakresie określenia ceny wydania zapasu, jest ograniczone przepisami księgowymi, które mają za zadanie zapewnienie przejrzystości sprawozdań finansowych. Przedsiębiorstwo nie może przy każdym wydaniu z magazynu dowolnie wybierać którą cenę wykorzystać, gdyż powodowałoby to sytuację, w której miałoby możliwość wpływania na wynik finansowy oraz wartość zapasów poprzez wybieranie niższych lub wyższych cen. Aby rozwiązać powyższe problemy, przedsiębiorstwa przyjmują jedną $\mathrm{z}$ metod wyceny zapasów ${ }^{8}$ :

1. metodę FIFO - First In, First Out - dosłownie: pierwsze weszło, pierwsze wyszło (metoda ceny najwcześniejszej). Jest to metoda wyceny zapasów i ich rozchodu, polegająca na księgowaniu rozchodu począwszy od tej jednostki towaru, która została przyjęta do magazynu najwcześniej. Zgodnie z FIFO w momencie wydawania zapasu z magazynu przedsiębiorstwo księguje wydanie zapasu, który był najwcześniej do magazynu przyjęty, a gdy jego ilość się wyczerpie - po cenie zapasu przyjętego jako następny w kolejności. FIFO uważana jest za skuteczną metodę wyceny, stosunkowo obiektywnie przedstawiającą wartość utrzymywanych przez przedsiębiorstwo zapasów. Metoda ta jest dopuszczana przez większość standardów rachunkowości na świecie, w tym polską ustawę o rachunkowości, IFRS (Międzynarodowe Standardy Rachunkowości) oraz US GAAP (Amerykańskie Standardy Rachunkowości),

2. metodę LIFO - Last In, First Out - dosłownie: ostatnie weszło, pierwsze wyszło (metoda ceny najpóźniejszej). Metoda ta polega na księgowaniu rozchodu, począwszy od ostatniej jednostki przyjętej do magazynu. Zgodnie $\mathrm{z}$ LIFO $\mathrm{w}$ momencie wydawania zapasu z magazynu przedsiębiorstwo księguje wydanie w wartości ostatnio przyjętego towaru, a gdy jego ilość się wyczerpie, po cenie poprzedniej. Metoda LIFO jest szczególnie lubiana przez przedsiębiorstwa ze względu na jej korzystny efekt podatkowy, zwłaszcza w okresie wysokiej inflacji. Inflacja bowiem powoduje, że kolejne dostawy towarów przyjmowane są po coraz wyższych cenach.

${ }^{8}$ Jak ustalić wtasna politykę rachunkowości?, op. cit., s. 2. 
Księgując rozchód, przedsiębiorstwo rejestruje możliwie najwyższy koszt, obniżając tym samym zysk do opodatkowania ${ }^{9}$,

3. metodę cen przeciętnych (metodę średniej ważonej ceny ewidencyjnej) - jest to metoda wyceny rozchodu zapasów, polegająca na jego księgowaniu przy wykorzystaniu średniej ważonej ceny ich nabycia. Zgodnie $\mathrm{z}$ metodą średniej ważonej w momencie wydawania zapasu $\mathrm{z}$ magazynu przedsiębiorstwo księguje wydanie $\mathrm{w}$ wartości średniej ważonej ceny towaru znajdującego się w magazynie. Za każdym razem, gdy towar jest przyjmowany do magazynu, ustalana jest nowa cena ewidencyjna. Metoda średniej ważonej jest stosunkowo popularna i często wykorzystywana w księgowości. Dość dobrze sprawdza się ona w przypadku zapasów, których ceny nie podlegają trendom, a raczej wahają się w pewnym przedziale cenowym. Metoda średniej ważonej wygładza te odchylenia, zmniejszając tym samym wahania zysku przedsiębiorstwa. Jest to zaleta tej metody, w porównaniu, np. z FIFO bądź LIFO. Metoda ta jest dozwolona przez przepisy księgowe i podatkowe w większości krajów.

Dla uwypuklenia możliwości kształtowania przez przedsiębiorstwo wyniku finansowego poprzez pozycję bilansu: „aktywa obrotowe - zapasy”, w tabeli 2 zaprezentowano różnice pomiędzy wariantowymi rozwiązaniami wyceny składników majątkowych przedsiębiorstwa.

Tabela 2. Wpływ metody wyceny zapasów na ich wartość

\begin{tabular}{|l|c|c|c|}
\hline \multicolumn{1}{|c|}{ Treść } & Ilość (szt.) & Cena (zl) & Wartość (zl) \\
\hline Założenia: & 100 & 5 & 500 \\
\hline $\begin{array}{l}\text { Stan początkowy produktu na 1. } \\
\text { dzień miesiąca }\end{array}$ & & & \\
\hline Zakup produktu & 110 & 6 & 660 \\
\hline 10 dnia miesiąca & 80 & 6,50 & 520 \\
\hline 15 dnia miesiąca & 180 & 6,70 & 1206 \\
\hline 25 dnia miesiąca &
\end{tabular}

Źródło: Opracowanie własne.

9 Warto zwrócić uwagę na fakt, że przy metodzie LIFO, w przypadku zapasów, które zawsze utrzymywane są w przedsiębiorstwie na pewnym bezpiecznym poziomie i nigdy nie są wydawane do zera, zapas ten będzie wyceniony w cenach, po których został przyjęty, często nawet wiele lat temu. Powoduje to, że wartość zapasów w sprawozdaniu finansowym spółek stosujących metodę LIFO może być zaniżona. $Z$ tego powodu niektóre standardy rachunkowości, między innymi MSR (Międzynarodowe Standardy Rachunkowości) nie pozwalają na stosowanie tej metody. 
Tabela 2. Wplyw metod wyceny...

\begin{tabular}{|c|c|c|c|}
\hline Treść & Ilość (szt.) & Cena (zl) & Wartość (zl) \\
\hline Zapas & 470 & - & 2886 \\
\hline \multicolumn{4}{|c|}{ Rozchód 30 dnia miesiąca 250 sztuk produktu, pozostało 220 sztuk } \\
\hline \multicolumn{4}{|c|}{ Metoda FIFO (pierwsze weszło - pierwsze wyszło) } \\
\hline & 100 & 5 & 500 \\
\hline & 110 & 6 & 660 \\
\hline & 40 & 6,50 & 260 \\
\hline razem & 250 & - & 1420 \\
\hline Zapas końcowy według FIFO & 220 & - & 1466 \\
\hline \multicolumn{4}{|c|}{ Metoda LIFO (ostatnie weszło - pierwsze wyszło) } \\
\hline & 180 & 6,70 & 1206 \\
\hline & 70 & 6,50 & 455 \\
\hline razem & 250 & - & 1661 \\
\hline Zapas końcowy według LIFO & 220 & - & 1225 \\
\hline \multicolumn{4}{|l|}{ Metoda ceny przeciętnej } \\
\hline $\begin{array}{l}\text { Przeciętna cena stanu } \\
\text { magazynowego }\end{array}$ & 470 & 6,1404 & 2886 \\
\hline razem & 250 & 6,1404 & 1535,11 \\
\hline $\begin{array}{l}\text { Zapas końcowy według ceny } \\
\text { przeciętnej }\end{array}$ & 220 & - & 1350,89 \\
\hline
\end{tabular}

Źródło: Opracowanie własne.

Różnica wartości zapasów na koniec okresu wycenianych metodami FIFO i LIFO,sięga blisko 16\%, natomiast metodami FIFO i ceny przeciętnej - około $8 \%$, zaś metodami LIFO i ceny przeciętnej - około $10 \%$. Wybór metody wyceny zapasów ma tym większy wpływ na kształtowanie wyniku finansowego przedsiębiorstwa (zysku lub straty), im większa wartościowo rotacja zapasów materiałów, towarów oraz produktów. Wybór metody wyceny zapasów ma ogromne znaczenie w firmach, w których zapasy występują, a więc w firmach produkcyjno-handlowych.

Podobne różnice $\mathrm{w}$ wyborze metody wyceny widoczne są w przypadku firm $\mathrm{z}$ obrotami dewizowymi. Ewidencja środków pieniężnych denominowanych $\mathrm{w}$ walutach obcych, wpływających z tytułu zapadających należności i wypływających $\mathrm{z}$ tytułu wymagalności zobowiązań, winna być prowadzona $\mathrm{w}$ formie rejestru walutowego. Rozchód i wycena ,zapasów” waluty, podobnie jak zapasów materiałów, produktów, towarów, winna być prowadzona $\mathrm{z}$ zastosowaniem jednej z wymienionych powyżej metod.

Przedstawione w niniejszym opracowaniu różnice nie wyczerpują tematu. Pozwalają jednak ocenić zakres rozbieżności 
i zdać sobie sprawę z możliwości kształtowania wyniku finansowego przez przedsiębiorstwo.

\section{Perspektywy rozwoju standardów rachunkowości}

W dobie globalizacji niezwykle istotną rolę odgrywają standardy rachunkowości, regulujące sposoby ujmowania informacji z systemów rachunkowości organizacji gospodarczych w sprawozdaniach finansowych ${ }^{10}$.

Stosowanie standardów rachunkowości pozwala na redukcję kosztów związanych $\mathrm{z}$ przetwarzaniem informacji zawartych w raportach finansowych przez ich użytkowników, co jest wynikiem przyjęcia powszechnie akceptowanej struktury i zakresu informacji w sprawozdaniu finansowym ${ }^{11}$.

Standaryzacja rachunkowości powoduje stosowanie przez wszystkie organizacje gospodarcze (np. spółki giełdowe) takich samych albo co najmniej zbliżonych praktyk rachunkowości, co wefekcie prowadzi do ujednolicenia zasad rachunkowości stosowanych w różnych krajach. Harmonizacja oznacza natomiast proces zwiększania porównywalności praktyk rachunkowości poprzez ustalenie zakresu ich zróżnicowania ${ }^{12}$.

Wyznacznikami przyszłej działalności przedsiębiorstw stają się wymiana międzynarodowa oraz planowanie finansowe $\mathrm{w}$ skali globalnej. Pociągają one za sobą zwiększone ryzyko handlowe w światowym obrocie gospodarczym, które w warunkach nieprecyzyjnych regulacji prawnych może doprowadzić do dalekosiężnych skutków finansowych.

Rozpatrując perspektywy rozwoju do roku 2020, dziedziną która w najbliższych latach może znaleźć odzwierciedlenie w praktyce jest rachunkowość wartości niematerialnych i prawnych.

\footnotetext{
${ }^{10}$ M. Gmytrasiewicz, Teoria rachunkowości a MSSF, [w:] Rachunkowość wczoraj, dziś i jutro, SKwP, Warszawa, 2007, s. 101.

${ }^{11}$ R. Ignatowski, Dokąd zmierzamy, czyli wizja rozwoju rachunkowości jako nauki i zawodu, [w:] Rachunkowość wczoraj, dziś i jutro, SKwP, Warszawa, 2007, s. 520.

12 M. K. Szpakowski, Standaryzacja a wzrost bogactwa narodów, www.szpakowski.org.pl/dokumenty/article/12/Standaryzacja_a_wzrost_bogac twa_narodow.pdf, dostęp na marzec 2012 r.
} 
Zdaniem Aldony Kameli-Sowińskiej ${ }^{13}$ koniecznym jest sporządzenie nowego międzynarodowego standardu rachunkowości w zakresie sprawozdawczości aktywów niematerialnych. Autorka uważa, że tradycyjna sprawozdawczość nadmiernie koncentruje się na aktywach finansowych (materialnych), a znaczna część generatorów wartości w gospodarce ma charakter niefinansowy. Obecne przepisy rachunkowe rozpoznają je tylko, gdy te są nabywane $\mathrm{z}$ zewnątrz. Przyszła rachunkowość powinna zwiększyć wagę i poszerzyć katalog aktywów niematerialnych i prawnych. Katalog mógłby zostać poszerzony, m.in. o relacje (lojalność i zaufanie) z klientami, dostawcami, inwestorami, czy kapitał ludzki (np. doświadczenie kierownictwa), reputację przedsiębiorstwa lub siłę marki.

Przyszła rachunkowość to rachunkowość „narzędziowa”, czyli taka, w której wyznacza się cel nadrzędny i koordynuje prace w obszarach wokół celu. W tym nowym, przyszłym ujęciu rachunkowości, wycena majątku i zdarzeń gospodarczych - tak przeszłych, jak i przyszłych, prognozowanych i realnych, staje się narzędziem rachunkowości. Nie różni się to w swej istocie od innych narzędzi, jakimi są amortyzacja, czy rezerwy. Rachunkowość wymaga odnalezienia i implementacji nowych narzędzi pomiaru, wyceny, ewidencji oraz raportowania. Powinny one przyczynić się do nadrobienia przez rachunkowość zaległości i przygotowania nowego sprawozdania, które sprosta wymaganiom wszystkich odbiorców ${ }^{14}$.

\section{Podsumowanie}

Stosowanie odmiennych, dopuszczalnych prawem, norm sporządzania sprawozdań finansowych, może w różny sposób ukształtować wynik finansowy przedsiębiorstwa. Wynik finansowy jest różnicą pomiędzy osiągniętymi w roku obrotowym przychodami i kosztami poniesionymi w celu ich osiągnięcia. Dodatni wynik finansowy jest nazywany zyskiem, natomiast ujemny stratą.

Informacje zawarte w sprawozdaniach finansowych wykorzystywane są do wyznaczania różnorodnych mierników oceny przedsiębiorstwa, np. wskaźników rentowności, płynności, sytuacji majątkowej, sytuacji finansowej. Ocenę poziomu poszczególnych wskaźników, jak wykazano na przykładzie wyceny zapasów, warto

13 A. Kamela-Sowińska, Dokąd zmierza rachunkowość po kryzysie, wykład okolicznościowy wygłoszony 16.06.2010r. w Stowarzyszeniu Księgowych w Polsce Oddział w Bydgoszczy z okazji obchodów rocznicy Stowarzyszenia.

${ }^{14}$ Ibidem. 
przeprowadzać w kontekście przyjętych przez przedsiębiorstwo metod i narzędzi polityki rachunkowości.

\section{Bibliografia}

1. Ustawa z dnia 29 września 1994 r. o rachunkowości, tj. Dz.U. 2009, nr 152, poz. 1223 z późn. zm.

2. Rozporządzenie Komisji (WE) Nr 1126/2008 z dnia 3 listopada 2008 r. przyjmujące określone międzynarodowe standardy rachunkowości zgodnie z rozporządzeniem (WE) nr 1606/2002 Parlamentu Europejskiego i Rady, Dziennik Urzędowy Unii Europejskiej z dnia 29.11.2008.

3. Jak ustalić własna politykę rachunkowości?, „Zeszyty Metodyczne Rachunkowości”, $\mathrm{nr}$ 7(295), Dodatek nr 7, Wydawnictwo Podatkowe GOFIN, 2011.

4. Gmytrasiewicz M., Teoria rachunkowości a MSSF, [w:] Rachunkowość wczoraj, dziś i jutro, SKwP, Warszawa, 2007.

5. Ignatowski R., Dokąd zmierzamy, czyli wizja rozwoju rachunkowości jako nauki i zawodu, [w:] Rachunkowość wczoraj, dziś i jutro, SKwP, Warszawa, 2007.

6. Kamela-Sowińska A., Dokad zmierza rachunkowość po kryzysie, wykład okolicznościowy wygłoszony $16.06 .2010 \mathrm{r}$. w Stowarzyszeniu Księgowych w Polsce Oddział w Bydgoszczy z okazji obchodów rocznicy Stowarzyszenia.

7. Pęksyk M., Zestawienie podobieństw i różnic pomiędzy MSSF/MSR a Ustawa o Rachunkowości, materiał szkoleniowy Eurofinance Training 2012.

8. Szpakowski M. K, Standaryzacja a wzrost bogactwa narodów, www.szpakowski.org.pl/dokumenty/article/12/Standaryzacja_a_w zrost_bogactwa_narodow.pdf.

9. Walińska E., Wencel A., Gad J., Jurewicz A., Sprawozdanie finansowe wedtug MSSF, Wolters Kluwer, Warszawa, 2011.

\section{Streszczenie}

Celem tego artykułu jest przedstawienie możliwości odmiennego kształtowania wyniku finansowego w rezultacie przyjęcia i realizacji określonej przez przedsiębiorstwo polityki rachunkowości. Szczególną uwagę zwrócono na wybrane różnice pomiędzy polityką rachunkowości prowadzoną w oparciu o ustawę o rachunkowości a polityką rachunkowości z uwzględnieniem Międzynarodowych Standardów Rachunkowości, w odniesieniu do wyceny zapasów. 
Summary

\section{WHAT CAUSES PROFIT (LOSS) FOR THE COMPANY? IMPACT OF ACCOUNTING POLICY ON THE FINANCIAL RESULT}

The purpose of this article is to discuss issues related to the possibilities of forming financial results of the company, using the chosen accounting policy. Particular attention is paid to the differences between accounting policy based on the Polish Act on Accounting and accounting policy with regard to the International Accounting Standards. 